\title{
Molecular characterization of the copper transport system in Staphylococcus aureus
}

\begin{abstract}
Correspondence
Radheshyam K. Jayaswal drjay@ilstu.edu
\end{abstract}

Received 16 May 2007

Revised 11 August 2007

Accepted 15 August 2007

\author{
Sutthirat Sitthisak, ${ }^{1}$ Lawrence Knutsson, ${ }^{1}$ James W. Webb ${ }^{2}$ \\ and Radheshyam K. Jayaswal ${ }^{1}$ \\ ${ }^{1}$ Department of Biological Sciences, Illinois State University, Normal, IL 61790, USA \\ ${ }^{2}$ Department of Chemistry, Illinois State University, Normal, IL 61790, USA
}

\begin{abstract}
The Staphylococcus aureus copA gene codes for a putative copper-translocating P-type ATPase and the downstream copZ gene codes for a copper chaperone. Genome database analyses demonstrate that these copper transport genes are highly conserved in $S$. aureus. The expression of $\operatorname{cop} A$ and $\operatorname{cop} Z$ was inducible by copper and to some extent by ferric and lead ions. A mutant strain containing a partially deleted $\operatorname{cop} A$ gene was more sensitive than the parent strain to copper, ferric and lead ions. The copper-sensitive phenotype was due to the accumulation of intracellular copper and thus the $\operatorname{cop} A$ product is involved in the export of copper ions. The metal-sensitive phenotype of the mutant was complemented in trans by a $2.7 \mathrm{kbp}$ DNA containing copA. We have cloned and overexpressed the metal-binding domains of CopA and CopZ and have shown by site-directed mutagenesis that the cysteine residues in the CXXC metal-binding motif in CopA are involved in copper binding and thus play an important role in copper transport in S. aureus.
\end{abstract}

\section{INTRODUCTION}

Staphylococcus aureus is a Gram-positive bacterium that is the causative agent of a wide variety of human infections, ranging from superficial skin and wound infections to deep abscesses and more serious sequelae such as septicaemia, urinary tract infections, osteomyelitis and endocarditis (Archer, 1998). S. aureus is capable of growing in a wide range of adverse environmental conditions, including media containing heavy metals. Understanding of metal resistance in staphylococci has progressed rapidly in the past 20 years. It has been well established that some of the genes for resistance to metal ions, such as cadmium, mercury, antimony and arsenic, are encoded by plasmids (Silver \& Phung, 1996). However, staphylococcal strains without plasmids also show resistance to heavy metal ions, such as zinc, cobalt and copper. We have previously identified genes involved in iron, zinc and cobalt transport in S. aureus (Xiong \& Jayaswal, 1998; Singh et al., 1999; Xiong et al., 2000; Cabrera et al., 2001). Some of these heavy metals, such as copper, iron and zinc, are necessary for life. However, little is known about genes involved in copper transport of $S$. aureus.

Copper is an essential trace element required by most organisms as a cofactor for numerous catabolic pathways and electron transport (Mason, 1976; Nicholas et al., 2002; Massaro, 2002). However, copper is toxic to cells at

Abbreviations: BCA, bicinchoninic acid; IAA, iminodiacetic acid-agarose; MBD, metal-binding domain. concentrations higher than physiological levels (Gaetke \& Chow, 2003). Therefore, the intracellular concentration of copper is controlled by copper transport systems encoded by cop operons, which maintain copper homeostasis (Cooksey, 1993). Copper transport systems have been studied in several micro-organisms. Among bacteria the best-characterized system is that of Enterococcus hirae, where the $\operatorname{cop}$ operon consists of four genes: $\operatorname{cop} Y, \operatorname{cop} Z$, $\operatorname{cop} A$ and $\operatorname{cop} B$. $\operatorname{cop} A$ and $\operatorname{cop} B$ encode P-type ATPases involved in copper uptake and efflux, respectively. The expression of $\operatorname{cop} A$ and $\operatorname{cop} B$ is induced by copper and further regulated by CopY, a repressor and CopZ, an activator (Solioz \& Stoyanov, 2003).

Recently we have identified genes involved in copper transport in S. aureus ATCC 12600 (Sitthisak et al., 2005). This strain contained a moo gene which encoded a multicopper oxidase and a copper-ATPase (cop) gene with $57 \%$ sequence similarity to $\operatorname{cop} B$ from Ent. hirae. However, these $m c o$ and cop genes were found only in S. aureus MRSA252 and ATCC 12600 but not in the other strains examined. Most of the sequenced $S$. aureus genomes contained another gene designated $\operatorname{cop} A$ which encodes a copper-translocating P-type ATPase followed by a copper metallochaperone $(\operatorname{cop} Z)$.

Copper-ATPase belongs to a large superfamily of CPx-Ptype ATPases (Lutsenko \& Kaplan, 1995; Solioz \& Vulpe, 1996; Rensing et al., 2000; Gatti et al., 2000). Translocation of cations across the cell membrane by copper-ATPases is achieved by utilizing the energy of hydrolysis of the 
terminal phosphate bound in ATP (Lutsenko \& Kaplan, 1995). The structure of CPx-type ATPase contains transmembrane helices and conserved structural elements. These elements are the phosphorylation domain (DKTGS/ $\mathrm{T}$ ), the phosphatase domain (TGES/A), the ATP-binding domain (MXGDGXNDXP), and the conserved putative metal-binding cysteine-proline- $\mathrm{x}$ sequence $(\mathrm{CPx})$ in the intramembrane domain. The hydrophilic $\mathrm{N}$-terminal part of CPx-type ATPases encompasses one to six heavy-metalbinding domains (MBDs) containing a GMTCXXC motif (Lutsenko et al., 1997; Deigweiher et al., 2004). The paired cysteine residues in this domain play an important role in heavy metal binding (Walker et al., 2002, 2004).

The copZ-encoded copper chaperone is a small protein involved in the intracellular delivery of copper to copperutilizing enzymes. It functions by protecting the intracellular milieu from copper toxicity and releasing copper to its partner proteins. In Ent. hirae, CopZ delivers copper to the CopY repressor. In a number of bacteria, the copZ gene is located adjacent to the genes encoding copper-ATPases (Pufahl et al., 1997). CopZ has also been shown to interact with CopA, which may be the site of copper loading of CopZ (Multhaup et al., 2001). Sequence similarities with the N-terminal metal-binding (CXXC) motif from copperATPases and metal chaperones have been identified in both eukaryotes and prokaryotes (Harrison et al., 2000).

In this study, we have characterized CopA, a copperATPase, and CopZ, a copper chaperone, with respect to their roles in copper transport, their metal-binding domains, and their expression in response to various heavy metals. We have shown that CopA is involved in copper efflux. Disruption of $\operatorname{cop} A$ resulted in the accumulation of intracellular copper and a copper-sensitive phenotype compared to the parent $S$. aureus strain. Northern blot analysis showed induction of $\operatorname{cop} A$ and $\operatorname{cop} Z$ transcription by copper and, to some extent, by iron and lead. We have cloned and overexpressed the MBDs of CopA and CopZ and have shown by mutagenesis that the cysteine residues in the CXXC metal-binding motif in CopA are involved in copper binding and thus play an important role in copper transport in $S$. aureus.

\section{METHODS}

Strains and culture conditions. S. aureus, Escherichia coli and plasmids used in this study are described in Table 1. S. aureus was grown in defined medium (DM) (Townsend \& Wilkinson, 1992) or tryptic soy broth (TSB) and E. coli was grown in Luria-Bertani broth (LB). When needed, ampicillin $\left(50 \mu \mathrm{g} \mathrm{ml}^{-1}\right)$, carbenicillin $(50 \mu \mathrm{g}$ $\left.\mathrm{ml}^{-1}\right)$, chloramphenicol $\left(10 \mu \mathrm{g} \mathrm{ml}^{-1}\right)$, erythromycin $\left(20 \mu \mathrm{g} \mathrm{ml}^{-1}\right)$ and tetracycline $\left(10 \mu \mathrm{g} \mathrm{ml}^{-1}\right)$ were added to the growth medium.

Construction of $\operatorname{copA}$ deletion mutant and complemented $\mathbf{S}$. aureus strains. Mutation in $\operatorname{cop} A$ was achieved by an in-frame deletion technique using plasmid pKOR1 as described by Bae \& Schneewind (2006). The upstream and downstream regions of $\operatorname{copA}$ were amplified by PCR using primers $\operatorname{cop} A-\mathrm{N} 1 / \operatorname{cop} A-\mathrm{N} 2$ and $\operatorname{cop} A-$ $\mathrm{C} 1 / \operatorname{cop} A-\mathrm{C} 2$ (Table 2), with S. aureus SH1000 DNA as a template and Taq polymerase enzyme (Promega). The two amplified fragments digested at the BamHI site were ligated. The ligated DNA was PCR amplified using primers N1and $\mathrm{C} 2$, which contained att sites, and integrated into pKOR1 using site-specific recombination. The recombinant plasmid was transformed into E. coli DH5 $\alpha$. Plasmids were purified and verified by sequencing. The resulting plasmids were transformed into S. aureus RN4220 and then SH1000. Co-integration

Table 1. Strains and plasmids used in this study

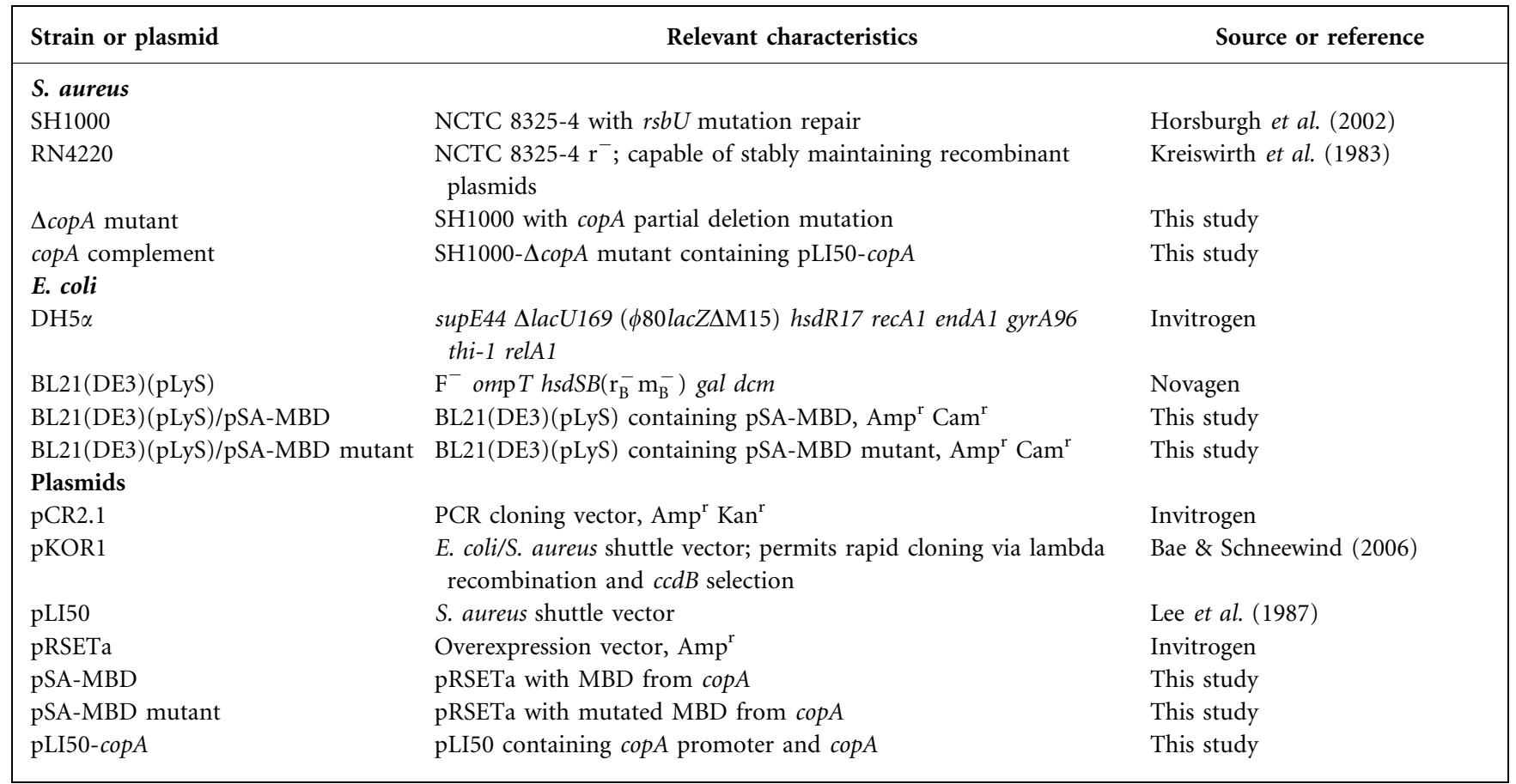


Table 2. Primers used in this study

\begin{tabular}{|c|c|c|}
\hline Name of gene/region & Primer & Sequence $\left(5^{\prime}-3^{\prime}\right)^{*}$ \\
\hline \multirow[t]{8}{*}{ MBD of $\operatorname{cop} A$} & MBD-N1 & GATATCACTGGTATGACTGCGGCCGCAGCG \\
\hline & & TCAAATCGTATCGAAAAG \\
\hline & MBD-N2 & CATTACAGGTATGACTGCGGCTGCAGCG \\
\hline & & TCAAGCCGTATTGAAAAAG \\
\hline & MBD-C1 & CTTTTCGATACGATTTGACGCTGCGGCCGCAGTCATACCAGTGATATC \\
\hline & MBD-C2 & CTTTTTCAATACGGCTTGACGCTGCAGCCGCAGTCATACCTGTAATG \\
\hline & MBD-F & GGATCCGTGGCTAATACGAAAAAAACAACATT \\
\hline & MBD-B & AAGCTTGCTTAATCAATT TATGTTCGCG \\
\hline \multirow[t]{7}{*}{$\operatorname{cop} A$} & $\operatorname{cop} A-\mathrm{N} 1$ & GGGGACAAGTTTGTACAAAAAAGCAGGCTG \\
\hline & & TGGCTAATACGAAAAAAACAACATT \\
\hline & $\operatorname{cop} A-\mathrm{N} 2$ & GGGGGATCCCACTTGTACCAACAGCAACAAGTA \\
\hline & $\operatorname{cop} A-\mathrm{C} 1$ & GGGGGATCCGGTTGGTAACCGTAAATTAATGGC \\
\hline & $\operatorname{cop} A-\mathrm{C} 2$ & GGGGACCACTTTGTACAAGAAAGCTGGGTCTAG GCATCTTTACGGCGTG \\
\hline & Com-F & GGAAGCTTGGTTGGTAACCGTAAATTAATGGC \\
\hline & Com-B & GGGAATTCCTAGGCATCTTTACGGCGTG \\
\hline \multirow[t]{2}{*}{$\operatorname{cop} Z$} & $\operatorname{cop} Z-F$ & CGGATCCATGTCACAAGAAATTTTAA \\
\hline & $\operatorname{cop} Z-B$ & GAAGCTTTTAAACGACATCGTAACCT \\
\hline
\end{tabular}

${ }^{*}$ Modified bases are indicated by bold letters. The site-specific recombination attB1 and attB2 sites are underlined. Restriction sites are in italic.

was induced by growing the bacteria at $43^{\circ} \mathrm{C}$. The integration mutants were subcultured at $30{ }^{\circ} \mathrm{C}$ and screened for the loss of tetracycline resistance. The partially deleted $\operatorname{cop} A$ mutant $(\triangle \operatorname{cop} A)$ was further confirmed by PCR and DNA sequencing using $\operatorname{cop} A-\mathrm{N} 1$ and $\operatorname{cop} A-\mathrm{C} 2$ primers. As shown in Fig. 1, there was a deletion of $1009 \mathrm{bp}$ from the $\operatorname{cop} A$ gene.

To complement the mutation of $\operatorname{cop} A$, a $2.7 \mathrm{~kb}$ fragment containing copA was cloned into the shuttle vector pLI50 (Lee et al., 1987). Two primers, Com-F and Com-B (Table 2) were designed and the PCR was performed using $S$. aureus SH1000 DNA as a template. The amplified fragment was cloned into pCR2.1 vector (Invitrogen) and subsequently into plasmid pLI50. The resulting plasmid was transformed into S. aureus RN4220. The plasmid was reisolated from S. aureus RN4220 and then transformed into the SH1000 $\Delta$ copA mutant. The transformants were tested for their ability to grow in TSB containing $1.5 \mathrm{mM} \mathrm{CuSO}_{4}$.

Northern blot analysis. RNA was isolated using a Qiagen kit. Ten micrograms of total RNA was electrophoresed in a $1 \%$ agarose/ $0.66 \mathrm{M}$ formaldehyde gel. RNA was transferred to nylon membrane (Millipore) and the blot was probed with radiolabelled $\operatorname{copA}(700 \mathrm{bp})$ or copZ probe $(200 \mathrm{bp})$ under aqueous phase conditions at $65{ }^{\circ} \mathrm{C}$. The probe was prepared using the Prime-a-Gene labelling system (Promega) in the presence of $\left[\alpha-{ }^{32} \mathrm{P}\right] \mathrm{dCTP}$.

Determination of intracellular copper, iron and lead concentration. To measure the copper, iron and lead content of the cells, overnight-grown cultures were diluted 1:100 in TSB supplemented

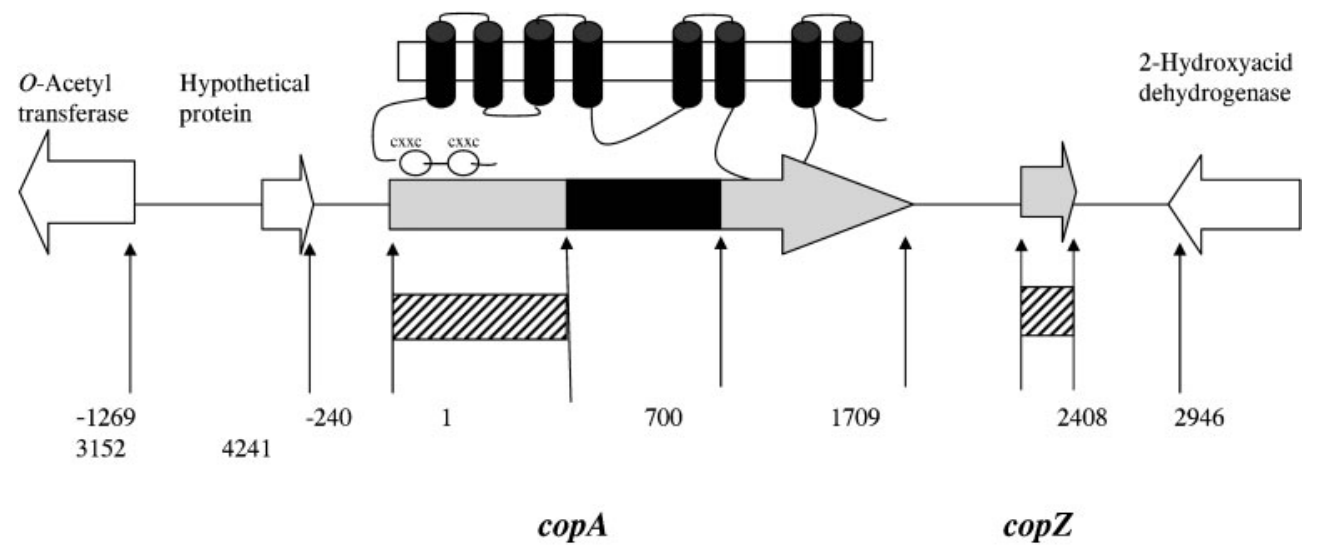

Fig. 1. Schematic representation of $\operatorname{cop} A$ and $\operatorname{cop} Z$ on the chromosome of $S$. aureus $\mathrm{SH} 1000$. The first nucleotide of $\operatorname{cop} A$ is used as the starting point for base pair numeration. The arrow indicates the gene and orientation. The thick black line indicates the region (700-1709 bp) that was deleted in the $\operatorname{cop} A$ mutant. Hatched lines indicate the DNA fragments used as probes. A schematic representation of the copper-ATPase, with two heavy-metal-binding CXXC motifs (open circles) and conserved transmembrane domains (filled cylinders), is shown above the $\operatorname{cop} A$ gene. 
with $0.5 \mathrm{mM} \mathrm{CuSO}_{4}, 0.5 \mathrm{mM} \mathrm{FeCl}_{3}$ or $0.5 \mathrm{mM} \mathrm{PbSO}_{4}$ and incubated at $37{ }^{\circ} \mathrm{C}$ until the $\mathrm{OD}_{600}$ reached 0.6. Cells were harvested and washed three times with $10 \mathrm{mM}$ Tris/ $\mathrm{HCl}(\mathrm{pH}$ 7.4) containing $1 \mathrm{mM}$ EDTA and once with MilliQ $\mathrm{H}_{2} \mathrm{O}$. Cells were dried overnight at $80{ }^{\circ} \mathrm{C}$ then dissolved in $30 \%$ nitric acid and the copper, iron and lead contents were measured by inductively coupled argon plasma atom emission spectrometry (Radford et al., 2003).

Cloning, expression and site-directed mutagenesis of the MBD encoded by copA. Two oligonucleotide primers, MBD-F and MBD$\mathrm{B}$ (Table 2), were designed with a BamHI site at the $5^{\prime}$ end and a HindIII site at the $3^{\prime}$ end of the DNA fragment. The PCR was performed using $S$. aureus genomic DNA as template and the PCR product was first cloned into pCR2.1 vector (Invitrogen) and subsequently into the BamHI and HindIII sites of pRSETa (Invitrogen). The resulting plasmid, pSA-MBD, was transformed into E. coli BL21(DE3)(pLysS) (Novagen) by electroporation. To overexpress the cloned gene product, the transformants were grown in LB containing ampicillin and chloramphenicol at $37{ }^{\circ} \mathrm{C}$ until the $\mathrm{OD}_{600}$ reached 0.5 and then the cells were induced for the expression of protein by the addition of $2.0 \mathrm{mM}$ IPTG for $3 \mathrm{~h}$. The induced cells were harvested, washed, and resuspended in lysis buffer $(20 \mathrm{mM}$ Tris/ $\mathrm{HCl}, \mathrm{pH} 7.4$, containing $145 \mathrm{mM} \mathrm{NaCl}$ ), Pellets were chilled on ice and homogenized by sonicator (Branson Sonifier 450) and cell debris was removed by centrifugation $10000 \mathrm{~g}$ at $4{ }^{\circ} \mathrm{C}$. The supernatants were applied to nickel-charged agarose-affinity columns (Novagen) and eluted with $200-400 \mathrm{mM}$ imidazole. Eluted fractions were subjected to $12.5 \%$ SDS-PAGE analysis. Fractions containing the overexpressed His-tag protein were pooled and dialysed against $25 \mathrm{mM}$ Tris/ $\mathrm{HCl}, \mathrm{pH}$ 8.0, containing $100 \mathrm{mM}$ sucrose, $50 \mathrm{mM} \mathrm{NaCl}$ and $1 \mathrm{mM}$ DTT.

PCR-based site-directed mutagenesis was performed in order to replace Cys residues by Ala in the MBD of CopA as described by Allemandou et al. (2003). The four primers MBD-N1, MBD-N2, MBD-C1 and MBD-C2 were used to exchange Cys at positions 16, 19, 83 and 86 for Ala residues. Mutations were confirmed by DNA sequencing. The fragment corresponding to the mutated $\mathrm{MBD}$ was gel purified and subcloned into the BamHI and HindIII sites of pRSETa, and the resulting plasmid, pSA-MBD mutant, was overexpressed in $E$. coli BL21(DE3)(pLysS) as described above. His-tag fragments from both the recombinant proteins were removed by using an enterokinase kit (Invitrogen) before performing the binding assay.

Bicinchoninic acid (BCA)-based copper-binding assay. The stoichiometry of copper binding by the putative wild-type MBD or the mutated MBD was determined by a BCA-based assay (Brenner \& Harris, 1995; Lutsenko et al., 1997). To determine the amount of copper bound to the protein in vitro, purified copper-free MBD or mutated MBD proteins at a concentration of $100 \mu \mathrm{g} \mathrm{ml}^{-1}$ were mixed with $\mathrm{CuCl}_{2}(20 \mu \mathrm{mol}$ copper per $\mu \mathrm{mol}$ protein $)$. After $10 \mathrm{~min}$ incubation at room temperature, unbound copper was removed by dialysis at $4{ }^{\circ} \mathrm{C}$ overnight and bound copper was measured by the BCA assay as described by Lutsenko et al. (1997).

Cation-binding specificity of the MBD by iminodiacetic acidagarose (IAA) chromatography. IAA columns equilibrated with different heavy metals were used to determine the cation-binding specificity as described by Lutsenko et al. (1997). Columns containing $100 \mu \mathrm{l}$ IAA (Sigma) were extensively washed with $50 \mathrm{mM}$ sodium phosphate buffer ( $\mathrm{pH} 7.5$ ) and then separately equilibrated with 10 volumes of the same buffer containing one of several heavy metal chloride compounds $\left(\mathrm{CdCl}_{2}, \mathrm{CuCl}_{2}, \mathrm{CoCl}_{2}, \mathrm{MnCl}_{2}\right.$ and $\left.\mathrm{FeCl}_{3}\right)$ at a final concentration of $1 \mathrm{mM}$. Excess metal ions were removed by extensive washing with sodium phosphate buffer and then $100 \mu \mathrm{g}$ purified MBD protein or mutated MBD protein $(\triangle \mathrm{MBD})$ was added to the resin and incubated for $10 \mathrm{~min}$ at room temperature. Columns were centrifuged to remove unbound proteins. Columns were washed with $500 \mu \mathrm{l}$ sodium phosphate buffer and bound proteins were eluted from the column with $50 \mathrm{mM}$ EDTA in sodium phosphate buffer. Both eluted and unbound proteins were concentrated and analysed by $12.5 \%$ SDS-PAGE.

Involvement of cysteine residues in the MBD. Involvement of the cysteine residues was demonstrated by the ability of copper to protect the cysteine residues in the MBDs against labelling with the cysteinedirected fluorescent reagent 7-diethylamino-3-(4'-maleimidylphenyl)-4-methylcoumarin (CPM), as described by Lutsenko et al. (1997) and Walker et al. (2002). Briefly, $50 \mu \mathrm{g}$ of purified MBD or $\triangle \mathrm{MBD}$ protein was incubated in the presence of different concentrations of copper for $10 \mathrm{~min}$, and then pulse-labelled with a 20 molar excess of CPM for $1 \mathrm{~min}$ in the dark. Proteins were separated by $15 \%$ SDS-PAGE. The CPM-labelled proteins were then monitored under UV light.

Molecular genetic procedures. Plasmid and chromosomal DNA isolation, DNA manipulation, digestion of DNA with restriction enzymes, DNA ligation, Northern blot analysis and PCRs were performed as described by Sambrook \& Russell (2001).

\section{RESULTS AND DISCUSSION}

\section{Analysis of copper transport genes in S. aureus}

The genome analysis of seven strains of $S$. aureus showed the presence of similar copper transport systems consisting of two genes, designated $\operatorname{cop} A(2408 \mathrm{bp})$ and $\operatorname{cop} Z$ (206 bp), separated by approximately 200-800 bp. The $\operatorname{cop} A$ gene is monocistronic, with no genes for potential regulatory proteins immediately upstream or downstream of the copA operon (Fig. 1). Upstream of $\operatorname{copA}$, potential -35 (TTGCAC) and -10 (TAAAAT) sequences, and a putative Shine-Dalgarno (GGGAGG) sequence, were identified. The molecular masses of the putative proteins encoded by $\operatorname{cop} A$ and $\operatorname{cop} Z$ were predicted to be 86.7 and $7.2 \mathrm{kDa}$, respectively. The copA gene encodes a coppertranslocating P-type ATPase protein exhibiting features of a CPx-type ATPase that pumps copper out of the cytoplasm (Huffman \& O'Halloran, 2001). CopA is a transmembrane protein that contains two heavy-metalbinding sites with CXXC motifs (MBD) in the N-terminal region, six conserved intramembrane helices, a phosphorylation domain, phosphatase domains and two additional transmembrane helices at the N-terminus. $\operatorname{cop} Z$ encodes a copper-binding chaperone protein which contains only an $\mathrm{MBD}$ at the $\mathrm{N}$-terminus. The putative characterization of CopA protein was achieved by using a computer program provided by San Diego Super Computer Center (http:// workbench.sdsc.edu/).

The genome database analyses suggested that the genes involved in copper transport are conserved in S. aureus. $\operatorname{cop} A$ and $\operatorname{cop} Z$ showed almost $100 \%$ sequence identity among S. aureus strains and about $75 \%$ with other staphylococcal species. We also performed PCR using primers from $\operatorname{cop} A$ and $\operatorname{cop} Z$, confirming that these genes are also present in other $S$. aureus strains such as ATCC 12600, H and Wood 46 whose genomes have not been 


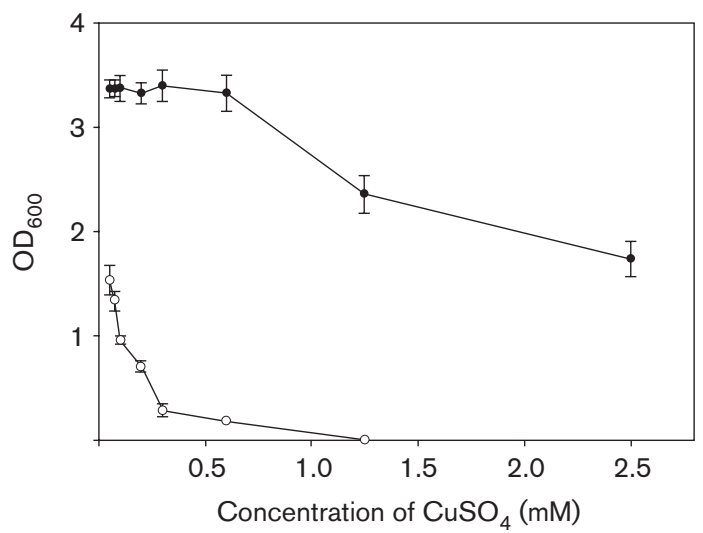

Fig. 2. Effect of copper on growth of $S$. aureus strain $\mathrm{SH} 1000$. Overnight grown cultures were diluted $1: 200$ in DM $(\bigcirc)$ and TSB $(\bullet)$, each containing various concentrations of $\mathrm{CuSO}_{4}$. Cultures were incubated at $37{ }^{\circ} \mathrm{C}$ with shaking. Growth was monitored by measuring the $\mathrm{OD}_{600}$ after $12 \mathrm{~h}$. Each point represents the mean \pm SD of three experiments.

sequenced (data not shown). The CopA from S. aureus showed $49 \%$ sequence identity with CopA of Ent. hirae. In addition, the CopA of $S$. aureus showed a similar CPC motif and two metal-binding motifs (CXXC). CopA, which is responsible for the copper influx in Ent. hirae, has a similar CXXC domain (Solioz \& Vulpe, 1996).

\section{Copper tolerance in S. aureus}

To determine the tolerance level of S. aureus SH1000 to copper, cells were grown in either chemically defined medium (DM) or TSB containing various concentrations of $\mathrm{CuSO}_{4}$. As shown in Fig. 2, the MIC of $\mathrm{CuSO}_{4}$ in TSB was around $2.5 \mathrm{mM}$ whereas in $\mathrm{DM}$ it was about $0.2 \mathrm{mM}$. The higher level of copper tolerance in TSB may be due to the faster growth rate and some factor(s) not available in DM.

\section{$\operatorname{cop} A$ and $\operatorname{cop} Z$ transcriptions are induced by copper}

Northern blot analysis was performed to evaluate the expression of $\operatorname{cop} A$ and $\operatorname{cop} Z$ during the growth of $S$. aureus in the presence of various metal ions. Total RNA was isolated from cultures exposed to various concentrations of copper, cobalt, cadmium, lead, iron and zinc. The expression of $\operatorname{cop} A$ and $\operatorname{cop} Z$ was induced when $S$. aureus $\mathrm{SH} 1000$ was grown in $\mathrm{DM}$ containing $\mathrm{CuSO}_{4}$. Northern blot analysis revealed the presence of two transcripts, of $\sim 2.4 \mathrm{~kb}$ and $\sim 2.0 \mathrm{~kb}$, when $\operatorname{cop} A$ was used as probe (Fig. 3a). The $2.4 \mathrm{~kb}$ band represents the copA transcript whereas the $2.0 \mathrm{~kb}$ transcript might represent multiple transcripts from the same gene, a degradation product of $\operatorname{cop} A$ or the transcript of some homologous gene. The expression of $\operatorname{cop} Z$ was also dependent on copper ion concentration and it was induced by as low as $5 \mu \mathrm{M}$ copper (Fig. 3b). A $0.2 \mathrm{~kb}$ transcript was detected when $\operatorname{cop} Z$ was used as probe, which seemed to be in good agreement with that predicted from the sequence data.

In order to determine the metal ion specificity of $\operatorname{cop} A$ and $\operatorname{cop} Z$ induction, $S$. aureus was grown in the presence of various heavy metal ions such as cadmium, cobalt, ferric, lead, manganese and zinc ions. In addition to copper, the transcription of $\operatorname{cop} A$ was to some extent induced by ferric

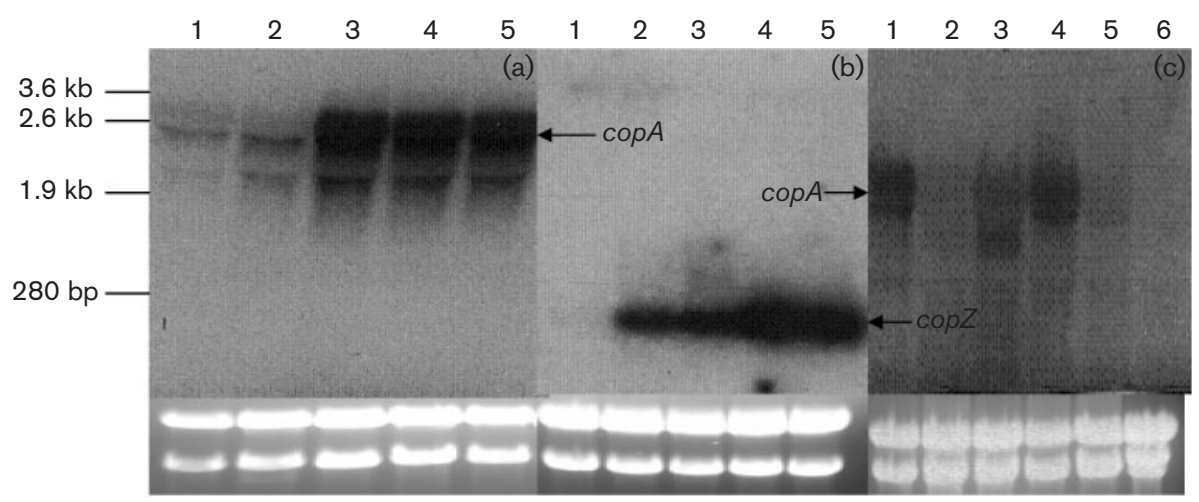

Fig. 3. Northern blot analysis to measure the expression of cop genes in response to various metal ions. $S$. aureus cells grown in DM under various conditions were collected at an $\mathrm{OD}_{600}$ of 0.4 and total RNA was isolated as described in Methods. (a, b) Ten micrograms of RNA was electrophoresed on formaldehyde gel (1.2\%) and transferred to nitrocellulose membrane, and the blots were probed with radiolabelled $\operatorname{cop} A(\mathrm{a})$ or $\operatorname{cop} Z$ (b). Response to copper. Lane 1, RNA from S. aureus grown in DM; lanes 2-5, RNA from S. aureus grown in $\mathrm{DM}_{\text {with }} \mathrm{CuSO}_{4}$ at $5 \mu \mathrm{M}$ (lane 2), $50 \mu \mathrm{M}$ (lane 3), $75 \mu \mathrm{M}$ (lane 4) and $100 \mu \mathrm{M}$ (lane 5). Positions of RNA molecular size markers $(\mathrm{kb})$ are shown on the left. (c) Induction of copA by other metal ions. RNA was extracted from S. aureus grown in $\mathrm{DM}_{\text {with }} 75 \mu \mathrm{M} \mathrm{CuSO}_{4}$ (lane 1); $50 \mu \mathrm{M} \mathrm{CoCl}_{2}$ (lane 2); $75 \mu \mathrm{M} \mathrm{PbSO}_{4}($ lane 3 ) $75 \mu \mathrm{M} \mathrm{FeCl} 3$ (lane 4), $50 \mu \mathrm{M} \mathrm{ZnCl}_{2}$ (lane 5) or $50 \mu \mathrm{M} \mathrm{MnCl}_{2}$ (lane 6) The bottom panels of (a-c) show ethidium-bromide-stained gels indicating that equivalent amounts of RNA were loaded to each lane. 
and lead ions (Fig. 3c). There was no effect of cobalt, cadmium, manganese, silver and zinc (Fig. $3 \mathrm{c}$ and data not shown). The induction of $\operatorname{cop} A$ gene by other metal ions such as silver has been reported (Rensing et al., 2000). We also measured the expression of $\operatorname{cop} A$ and $\operatorname{cop} Z$ during the growth cycle. The expression of $\operatorname{cop} A$ and $\operatorname{cop} Z$ was growth phase dependent: both genes were expressed to a higher level in the exponential phase than in the stationary phase (data not shown). As described above we have not found either any potential regulatory gene or possible regulatory sequences upstream of $\operatorname{cop} A$. Therefore, it is difficult to predict the mechanism by which copper regulates the expression of $\operatorname{cop} A$ and $\operatorname{cop} Z$ in $S$. aureus

\section{copA mutation induces copper, iron and lead sensitivity in $S$. aureus}

A partial deletion in the $\operatorname{cop} A$ gene was constructed as described in Methods. To examine the effect of mutation in $\operatorname{copA}$, S. aureus strains $\mathrm{SH} 1000$ (parent) and the $\operatorname{copA}$ partial deletion mutant $(\triangle \operatorname{cop} A)$ strains were grown in DM with or without copper. There was no difference in the growth rate between parent and $\triangle c o p A$ strains in DM without copper (data not shown). However, in the presence of $75 \mu \mathrm{M}$ copper sulfate the $\Delta c o p A$ strain showed increased copper sensitivity (Fig. 4a). There was a significant difference in growth rate between the wild-type and the mutant strain $(P=0.004)$. The $\triangle \operatorname{cop} A$ mutant was also tested for ferric iron and lead sensitivity, as the Northern analysis suggested that the expression of $\operatorname{cop} A$ is also induced by ferric and lead ions. As shown in Fig. 4(b, c), the $\Delta \operatorname{cop} A$ mutant was also sensitive to ferric and lead ions. There was a significant difference in growth rate between the wild-type and the mutant strain $(P=0.004$ and 0.023 respectively). In $B$. subtilis, mutation in $\operatorname{cop} A$ sensitized the cells to copper but not to other metal ions (Gaballa \& Helmann, 2003).

Complementation experiments were performed to provide genetic evidence that the copper, ferric and lead sensitivity is due to the mutation in the copA gene. A $2.7 \mathrm{~kb}$ fragment containing the $\operatorname{cop} A$ gene with promoter sequences was cloned in the shuttle vector pLI50 and transformed into the $\triangle c o p A$ mutant. The complemented strain was tested for growth in the presence of copper, ferric ions and lead. As shown in Fig. 4(a, b), the complemented strain was able to grow at the same rate as the parent strain in the presence of copper and iron but it grew slightly slower in the presence of lead (Fig. 4c). These results suggested that the copper-, ferric- and lead-sensitive phenotype of the mutant was due to the mutation in the $\operatorname{cop} A$ gene. The capacity to transport
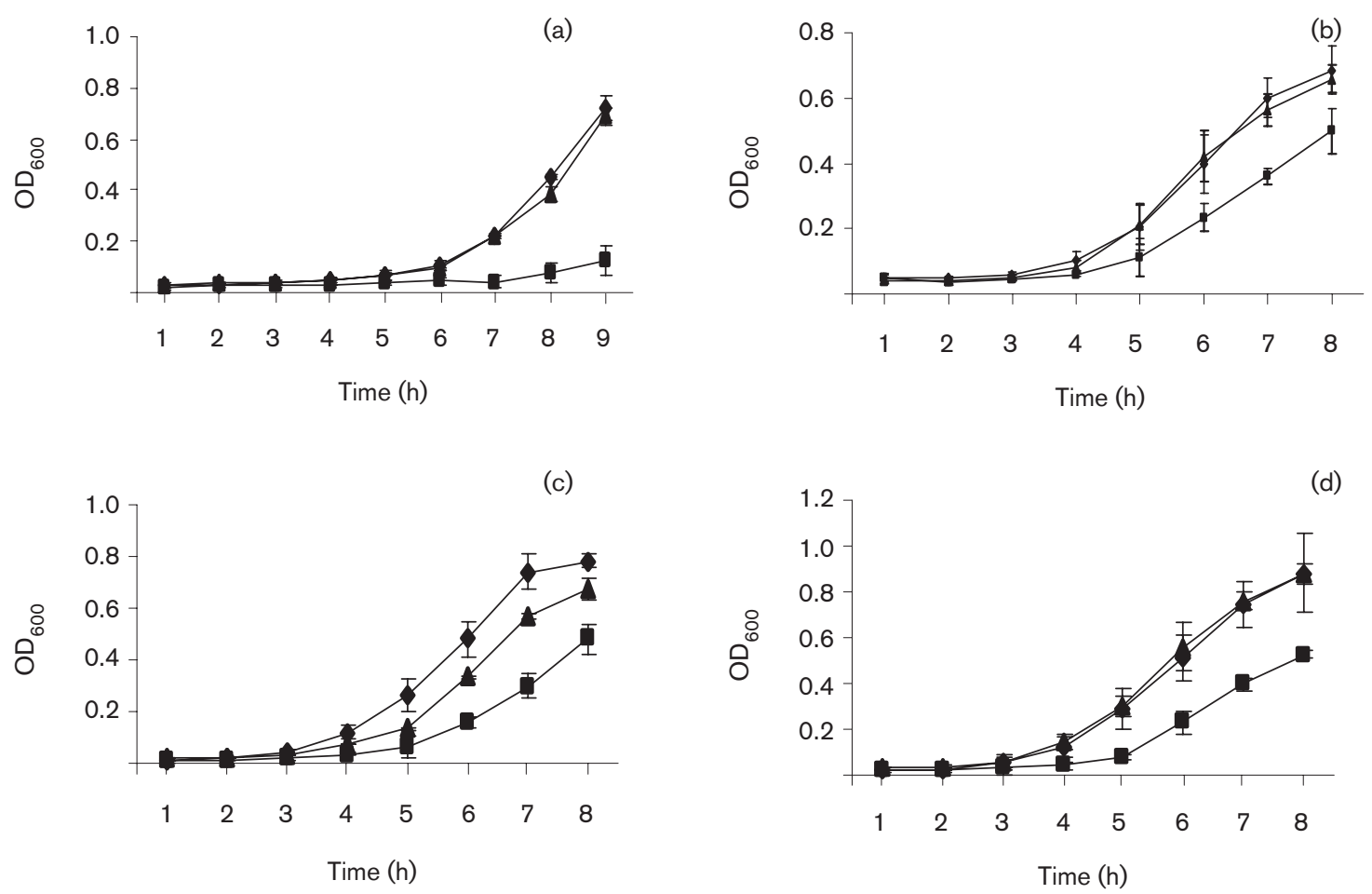

Fig. 4. Effect of copper (a), iron (b), lead (c) and hydrogen peroxide (d) on growth of $S$. aureus strains. Overnight cultures were

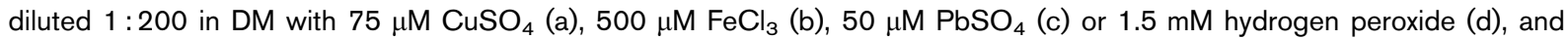
incubated at $37{ }^{\circ} \mathrm{C}$ with shaking. Cell growth was monitored by measuring $\mathrm{OD}_{600}$. $\boldsymbol{\diamond}$. Wild-type; $\boldsymbol{\square}, \operatorname{cop} A$ mutant $; \boldsymbol{\Delta}, \operatorname{cop} A$ complemented strain. Each point represents the mean \pm SD of three experiments. 
diverse metals by CPX-ATPase has been shown in Archaeoglobus fulgidus, B. subtilis and other micro-organisms (Arguello et al., 2003; Gaballa \& Helmann, 2003). In addition, association between genes for copper transport and genes for iron transport has been found in Saccharomyces cerevisiae (van Bakel et al., 2004, 2005). Since both lead and iron can induce the transcription of the $\operatorname{cop} A$, this further suggests that $\operatorname{cop} A$ may function as a co-transporter for these ions.

\section{Mutation in copA causes hydrogen peroxide sensitivity}

Another phenotype of the $\Delta \operatorname{cop} A$ mutant was found to be its increased sensitivity to hydrogen peroxide. As shown in Fig. 4(d), the growth of $\triangle$ copA mutant in DM containing $1.5 \mathrm{mM} \mathrm{H}_{2} \mathrm{O}_{2}$ was slower compared to the parent strain. The $\triangle$ copA mutant's hydrogen peroxide tolerance was restored to the normal level, as observed in the parent strain, by complementation. We also checked the tolerance levels of the $\triangle \operatorname{cop} A$ mutant to another oxidative agent, paraquat, and found no difference (data not shown). The precise mechanism by which the $\Delta c o p A$ mutant becomes sensitive to hydrogen peroxide is not clear. However, as mentioned above CopA is a $\mathrm{Cu}(\mathrm{I})$-translocating P-type ATPase, and mutation in $\operatorname{cop} A$ causes the accumulation of $\mathrm{Cu}^{+}$in the mutant cells. In addition, the $\Delta \operatorname{cop} A$ mutant showed increased iron sensitivity (Fig. $4 \mathrm{~b}$ ) and a higher concentration of intracellular iron (Table 3). Iron and copper are both capable of catalysing the formation of hydroxyl radicals $\left(\mathrm{OH}^{*}\right)$ from $\mathrm{H}_{2} \mathrm{O}_{2}$ via the Haber-Weiss reaction (Bremner, 1998; Pierre \& Fontecave, 1999), which may be the cause of the $\mathrm{H}_{2} \mathrm{O}_{2}$-sensitive phenotype.

\section{Functional analysis of $\operatorname{cop} A$}

The intracellular concentration of copper was measured to prove that $\operatorname{cop} A$ was involved in the efflux of copper ions and that copper sensitivity was due to the accumulation of copper. S. aureus strains grown in TSB medium containing $0.5 \mathrm{mM}$ copper were collected, washed and digested. They were used to determine intracellular copper concentration by inductively coupled argon plasma atom emission spectrometry (see Methods). As shown in Table 3,

Table 3. Intracellular metal content of $S$. aureus strains

Each value represents the mean $\pm \mathrm{SD}$ of three experiments.

\begin{tabular}{|lccc|}
\hline \multirow{2}{*}{ S. aureus strain } & \multicolumn{2}{c|}{ Metal content [p.p.m. $(\mathbf{m g} \text { dry wt })^{-\mathbf{1}}$ ] } \\
\cline { 2 - 4 } & Copper & Iron & Lead \\
\hline Wild-type & $0.0095 \pm 0.001$ & $0.0024 \pm 0.001$ & $0.036 \pm 0.02$ \\
Mutant $(\Delta \operatorname{cop} A)$ & $0.068 \pm 0.02$ & $0.0085 \pm 0.002$ & $0.086 \pm 0.01$ \\
Complemented & $0.0078 \pm 0.004$ & $0.001 \pm 0.001$ & $0.035 \pm 0.03$ \\
& & & \\
\hline
\end{tabular}

intracellular copper concentrations increased over sevenfold in the $\operatorname{cop} A$ mutant when cultures were grown in TSB containing $0.5 \mathrm{mM} \mathrm{CuSO}_{4}$ compared to the parent strain $(P=0.0001)$. In the $\triangle \operatorname{cop} A$ complemented strain the concentrations of intracellular copper were equivalent to the concentrations in the parent strain. We also determined the colony count of cells grown in the presence of various ions. There were slightly fewer c.f.u. $\mathrm{ml}^{-1}$ in the mutant compared to wild-type and the complemented strains (data not shown). However, this difference cannot account for a several-fold increase in the concentration of intracellular ions. The accumulation of high concentrations of copper ions in the $\triangle \operatorname{cop} A$ mutant cells is indicative of their inability to efflux copper. The lower concentration in the complemented strain also supports the idea that CopA functions as a copper transporter. Under normal physiological conditions, $\operatorname{cop} A$ and $\operatorname{cop} Z$ are not transcribed in either the mutant or the parent strain. This suggests that the $\operatorname{cop} A$ is not essential for the growth of $S$. aureus under normal conditions but is required under conditions of high copper.

The intracellular concentrations of iron and lead were also measured (Table 3). The concentrations of these metals were higher in the $\triangle$ copA mutant when cultures were grown in TSB containing $0.5 \mathrm{mM} \mathrm{FeCl}_{3}$ or $0.5 \mathrm{mM} \mathrm{PbSO}_{4}$ $(P=0.001$ and 0.029 respectively). The accumulation of iron and lead ions in the $\triangle \operatorname{cop} A$ mutant cells may be due to the inability of these cells to efflux both metal ions.

\section{Characterization of the MBD in copA}

It has been shown that the $\mathrm{N}$-terminal domains of the Wilson's and Menkes disease proteins bind copper selectively in vivo as well as in vitro (Lutsenko et al., 1997; DiDonato et al., 1997). Here we have investigated the role of the putative MBD in CopA protein from $S$. aureus strain SH1000. The MBD, containing $\mathrm{C}^{16} \mathrm{XXC}^{19}$ and $\mathrm{C}^{83} \mathrm{XXC}^{86}$ motifs, was cloned and overexpressed (Fig. $5 \mathrm{a}$ ) as described in Methods, and its copper-binding ability was determined in vitro.

The requirement for cysteine residues in the MBD was investigated by site-directed mutagenesis of the CXXC motifs, in which four cysteine residues in the motifs were replaced by alanine. By using the BCA-based copperbinding assay, the stoichiometry of copper binding to the $\mathrm{MBD}$ in vitro was $1.54 \pm 0.2 \mu \mathrm{mol}$ copper per $\mu \mathrm{mol}$ protein, whereas $0.52 \pm 0.2 \mu \mathrm{mol}$ copper bound per $\mu \mathrm{mol}$ mutated MBD protein. Our experiments in a BCA-based assay showed that copper binds to the MBDs both in vitro and in vivo in the presence of the reducing agent DTT. This suggested that MBDs purified in the presence of DTT are in the reduced form, containing free thiol groups in the paired cysteine residues, and bind to copper better than oxidized MBDs (disulfide bound). Since the thiol groups are easily oxidized by oxygen, DTT is required in the buffer to maintain the reduced form of the MBD protein. 


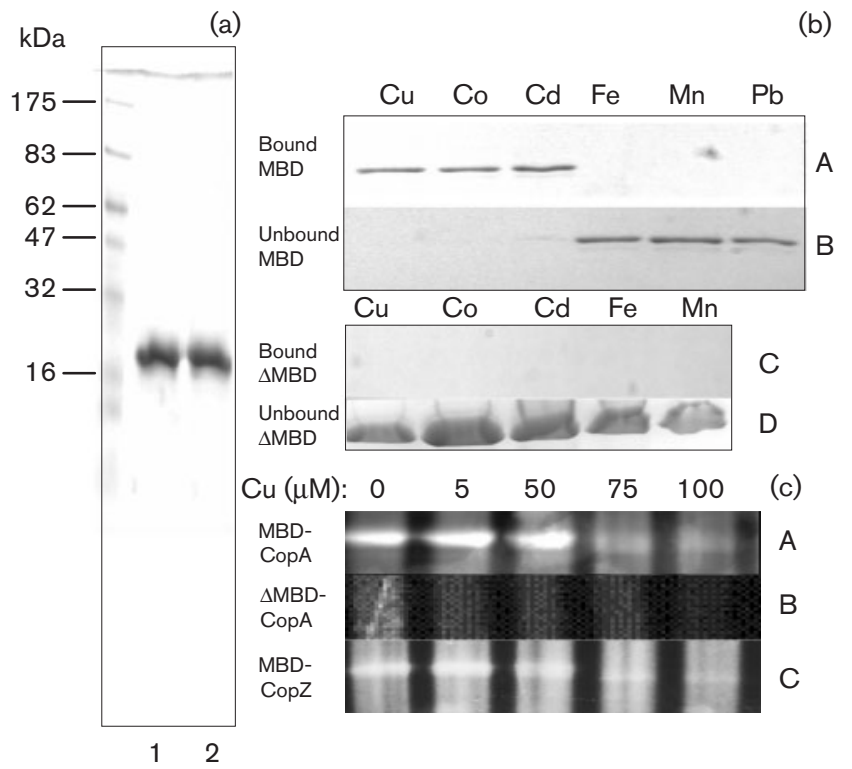

Fig. 5. (a) MBD protein (lane 1) and Cys-mutated MBD protein (lane 2) analysed on a $12.5 \%$ SDS-polyacrylamide gel. (b) Binding of overexpressed MBD of CopA or $\triangle \mathrm{MBD}$ protein to IAA-resin, equilibrated with different metal ions. IAA-resin was charged with different heavy metal as indicated above the respective lane. Bound and unbound proteins were concentrated and subjected to $12.5 \%$ SDS-PAGE (see Methods for details). Row A, bound MBD protein; row $B$, unbound $M B D$ protein; row $C$, bound $\triangle M B D$ protein; row $\mathrm{D}$, unbound $\triangle \mathrm{MBD}$ protein. (c) Fluorescent labelling to examine the involvement of cysteine residues in the MBDs. MBD proteins $(50 \mu \mathrm{g})$ were incubated with the fluorescent reagent 7 diethylamino-3-(4'-maleimidylphenyl)-4-methylcoumarin in the presence of the indicated copper chloride concentrations and then subjected to $12.5 \%$ SDS-PAGE. Fluorescence was detected under UV light. Row $A, M B D$, row $B, \triangle M B D$; row $C$, MBD-CopZ.

In addition, we tested the binding by using IAA chromatography, equilibrated with different heavy metals (copper, cobalt, cadmium, iron and manganese and lead). As shown in Fig. 5b, A, binding was detected for copper-, cobalt- and cadmium-equilibrated columns eluted by EDTA but no binding was observed for iron-, manganeseor lead-equilibrated columns (Fig. 5b, B). Based on in vivo studies (data presented in Figs 3 and 4) it was expected that iron and lead would bind to the MBD in IAA chromatography. In in vitro studies, IAA chromatography showed that cobalt binds to the MBD, but it does not induce the transcription of $\operatorname{cop} A$ in Northern blot analysis (Fig. 3). The discrepancies in these results are difficult to interpret, but it might be that in vivo metal ions regulate the transcription of the $\operatorname{cop} A$ through a separate metal-binding regulatory protein. In vitro binding of various metals to the MBD of the CopA protein may depend on conditions such as $\mathrm{pH}$, ion concentration, binding constant, redox state of metals, etc. The MBD of CopA and other copper P-type ATPases is thought to initially bind copper and then deliver it to a distinctly separate copper-transporting site (probably within the transmembrane domains). It is conceivable that iron binds directly to the copper transporting site without first interacting with the MBD. In this study we wanted to examine the role of the MBD of $\operatorname{cop} A$. We have shown that it binds copper in vitro, and a copper-protein complex may play an important role during copper transport. Northern blot data showed that copper regulates $\operatorname{cop} A$ expression. In vitro the $\mathrm{MBD}$ binds cadmium and cobalt, but these metals do not regulate $\operatorname{cop} A$ expression. It may be that the conformation of the protein when it binds to these non-copper metals is incompatible with gene expression. Of course, metal binding to the MBD and gene expression are two different phenomena and not necessarily correlated. In vitro studies suggest the role of the CXXC motifs in metal binding. When the Cys-mutated MBD protein was used in this experiment no binding was observed under any condition (Fig. 5b, C and D).

To further confirm the role of cysteine residues in the $\mathrm{MBD}$, a cysteine-directed fluorescent reagent, 7-diethylamino-3-(4'-maleimidylphenyl)-4-methylcoumarin was used as described in Methods. As shown in Fig. 5(c, A and $\mathrm{C}$ ), when the MBDs from $\operatorname{cop} A$ and $\operatorname{cop} Z$ were incubated with fluorescent reagent in the presence of various concentrations of copper, a concentration of copper above $50 \mu \mathrm{M}$ prevented the fluorescent labelling of cysteine residues. There was no effect on fluorescent labelling when the MBD protein was incubated with other heavy metals. The labelling of the Cys-mutated MBD protein with fluorescent reagent was not observed, whether copper was present or not (Fig. 5c, B). These results confirmed that cysteine binds to copper and the formation of a copper-protein complex may play an important role during copper transport.

\section{Concluding remarks}

We have characterized a $\operatorname{cop} A$ gene responsible for the efflux of mainly copper ions and probably also ferric and lead ions in $S$. aureus. The cop $Z$ gene encodes a copperbinding chaperone most probably involved in the intracellular delivery of copper to copper-utilizing enzymes. The expression of $\operatorname{cop} A$ and $\operatorname{cop} Z$ is inducible by copper and to some extent by ferric and lead ions. In vitro metal-binding studies showed that copper, cadmium and cobalt can bind to the MBD of CopA. We are currently investigating the regulation aspects of $\operatorname{cop} A$ and $\operatorname{cop} Z$ genes in $S$. aureus using DNA microarray technology.

\section{ACKNOWLEDGEMENTS}

We are grateful to Dr Anthony Otsuka for critical reading of this manuscript. This work has been partially supported by a grant from the NIH (GM071363) to R. K. J. 


\section{REFERENCES}

Allemandou, F., Nussberger, J., Brunner, H. R. \& Brakch, N. (2003). Rapid site-directed mutagenesis using two-PCR-generated DNA fragments reproducing the plasmid template. J Biomed Biotechnol 2003, 202-207.

Archer, G. L. (1998). Staphylococcus aureus: a well-armed pathogen. Clin Infect Dis 26, 1179-1181.

Arguello, J. M., Mandal, A. K. \& Mana-Capelli, S. (2003). Heavy metal transport CPx-ATPases from the thermophile Archaeoglobus fulgidus. Ann N Y Acad Sci 986, 212-218.

Bae, T. \& Schneewind, O. (2006). Allelic replacement in Staphylococcus aureus with inducible counter-selection. Plasmid 55, 58-63.

Bremner, I. (1998). Manifestations of copper excess. Am J Clin Nutr 67 (5 Suppl.), 1069S-1073S.

Brenner, A. J. \& Harris, E. D. (1995). A quantitative test for copper using bicinchoninic acid. Anal Biochem 226, 80-84.

Cabrera, G., Xiong, A., Uebel, M., Singh, V. K. \& Jayaswal, R. K. (2001). Molecular characterization of the iron-hydroxamate uptake system in Staphylococcus aureus. Appl Environ Microbiol 67, 1001-1003.

Cooksey, D. A. (1993). Copper uptake and resistance in bacteria. $\mathrm{Mol}$ Microbiol 7, 1-5.

Deigweiher, K., Drell, T. L., Prutsch, A., Scheidig, A. J. \& Lubben, M. (2004). Expression, isolation, and crystallization of the catalytic domain of $\operatorname{cop} B$, a putative copper transporting ATPase from the thermoacidophilic archaeon Sulfolobus solfataricus. J Bioenerg Biomembranes 36, 151-159.

DiDonato, M., Narindrasorasak, S., Forbes, J. R., Cox, D. W. \& Sarkar, B. (1997). Expression, purification, and metal-binding properties of the $\mathrm{N}$ terminal domain from the Wilson disease putative copper-transporting ATPase (ATP7B). J Biol Chem 272, 33279-33282.

Gaballa, A. \& Helmann, J. D. (2003). Bacillus subtilis CPx-type ATPases: characterization of $\mathrm{Cd}, \mathrm{Zn}$, $\mathrm{Co}$ and $\mathrm{Cu}$ efflux systems. Biometals 16, 497-505.

Gaetke, L. M. \& Chow, C. K. (2003). Copper toxicity, oxidative stress, and antioxidant nutrients. Toxicology 189, 147-163.

Gatti, D., Mitra, B. \& Rosen, B. P. (2000). Escherichia coli soft metal ion-translocating ATPases. J Biol Chem 275, 34009-34012.

Harrison, M. D., Jones, C. E., Solioz, M. \& Dameron, C. T. (2000). Intracellular copper routing: the role of copper chaperones. Trends Biochem Sci 25, 29-32.

Horsburgh, M. J., Aish, J. L., White, I. J., Shaw, L., Lithgow, J. K. \& Foster, S. J. (2002). $\sigma^{\mathrm{B}}$ modulates virulence determinant expression and stress resistance: characterization of a functional $r s b U$ strain derived from Staphylococcus aureus 8325-4. J Bacteriol 184, 5457-5467.

Huffman, D. L. \& O'Halloran, T. V. (2001). Function, structure, and mechanism of intracellular copper trafficking proteins. Annu Rev Biochem 70, 677-701.

Kreiswirth, B. N., Lofdahl, M. S., Betley, M. J., O' Reilly, M., Schlievert, P. M., Bergdoll, M. S. \& Novick, R. P. (1983). The toxic shock syndrome exotoxin structural gene is not detectably transmitted by prophage. Nature 305, 709-712.

Lee, C. Y., Schmidt, J. J., Johnson-Winergar, A. D., Spero, L. \& landolo, J. J. (1987). Sequence determination and comparison of the exfoliative toxin A and toxin B genes from Staphylococcus aureus. J Bacteriol 169, 3904-3909.

Lutsenko, S. \& Kaplan, J. H. (1995). Organization of P-type ATPases: significance of structural diversity. Biochemistry 34, 15607-15613.

Lutsenko, S., Petrukhin, K., Cooper, M. J., Gilliam, C. T. \& Kaplan, J. H. (1997). N-terminal domains of human copper-transporting adenosine triphosphatases (the Wilson's and Menkes disease proteins) bind copper selectively in vivo and in vitro with stoichiometry of one copper per metal binding repeat. J Biol Chem 272, 18939-18944.

Mason, H. S. (1976). Binuclear copper clusters as active sites for oxidases. Adv Exp Med Biol 74, 464-469.

Massaro, E. J. (2002). Handbook of Copper Toxicology, pp. 624. Totowa, NJ: Humana Press.

Multhaup, G., Strausak, D., Bissig, K. D. \& Solioz, M. (2001). Interaction of the CopZ copper chaperone with the CopA copper ATPase of Enterococcus hirae assessed by surface plasmon resonance. Biochem Biophys Res Commun 288, 172-177.

Nicholas, K. M., Wentworth, P., Harwig, C. W., Wentworth, A., Shafton, D. \& Janda, K. D. (2002). A cofactor approach to copperdependent catalytic antibodies. Proc Natl Acad Sci U S A 99, 2648-2653.

Pierre, J. L. \& Fontecave, M. (1999). Iron and activated oxygen species in biology: the basic chemistry. Biometals 12, 195-199.

Pufahl, R. A., Singer, C. P., Peariso, K. L., Lin, S. J., Schmidt, P. J., Fahrni, C. J., Culotta, C., Penner-Hahn, J. E. \& O'Halloran, T. V. (1997). Metal ion chaperone function of the soluble $\mathrm{Cu}(\mathrm{I})$ receptor Atx1. Science 278, 853-856.

Radford, D. S., Kihlken, M. A., Borrelly, G. P., Harwood, C. R., Le Brun, N. E. \& Caver, J. S. (2003). CopZ from Bacillus subtilis interacts in vivo with a copper exporting CPx-type ATPase CopA. FEMS Microbiol Lett 220, 105-112.

Rensing, C., Bin, F., Sharma, R., Mitra, B. \& Rosen, B. P. (2000). CopA: an Escherichia coli $\mathrm{Cu}(\mathrm{I})$-translocating P-type ATPase. Proc Natl Acad Sci U S A 97, 652-656.

Sambrook, J. \& Russell, D. (2001). Molecular Cloning: a Laboratory Manual, 3rd edn. Cold Spring Harbor, NY: Cold Spring Harbor Laboratory.

Silver, S. \& Phung, L. T. (1996). Bacterial heavy metal resistance: new surprises. Annu Rev Microbiol 50, 753-789.

Singh, V. K., Xiong, A., Usgaard, T., Chakrabarty, S., Deora, R., Misra, T. \& Jayaswal, R. K. (1999). ZntR is an autoregulatory protein and negatively regulates the chromosomal zinc resistance operon of $S$. aureus. Mol Microbiol 33, 200-207.

Sitthisak, S., Howieson, K., Amezola, C. \& Jayaswal, R. K. (2005). Characterization of a multicopper oxidase gene from Staphylococcus aureus. Appl Environ Microbiol 71, 5650-5653.

Solioz, M. \& Stoyanov, J. V. (2003). Copper homeostasis in Enterococcus hirae. FEMS Microbiol Rev 27, 183-195.

Solioz, M. \& Vulpe, C. (1996). CPx-type ATPases: a class of P-type ATPases that pump heavy metals. Trends Biochem Sci 21, 237-241.

Townsend, D. E. \& Wilkinson, B. J. (1992). Proline transport in Staphylococcus aureus: a high-affinity system and a low-affinity system involved in osmoregulation. J Bacteriol 174, 2702-2710.

van Bakel, H., Huynen, M. \& Wijmenga, C. (2004). Prokaryotic diversity of the Saccharomyces cerevisiae Atxlp-mediated copper pathway. Bioinformatics 20, 2644-2655.

van Bakel, H., Strengman, E., Wijmenga, C. \& Holstege, F. C. (2005). Gene expression profiling and phenotype analyses of $S$. cerevisiae in response to changing copper reveals six genes with new roles in copper and iron metabolism. Physiol Genomics 22, 356-367.

Walker, J. M., Tsivkovskii, R. \& Lutsenko, S. (2002). Metallochaperone Atox1 transfers copper to the $\mathrm{NH}_{2}$-terminal domain of the Wilson's disease protein and regulates its catalytic activity. J Biol Chem 277, 27953-27959.

Walker, J. M., Huster, D., Ralle, M., Morgan, C. T., Blackburn, N. J. \& Lutsenko, S. (2004). The N-terminal metal-binding site 2 of the 
Wilson's disease protein plays a key role in the transfer of copper from atox1. J Biol Chem 279, 15376-15384.

Xiong, A. \& Jayaswal, R. K. (1998). Molecular characterization of a chromosomal determinant conferring resistance to zinc and cobalt ions in Staphylococcus aureus. J Bacteriol 180, 4024-4029.
Xiong, A., Singh, V. K., Cabrera, G. \& Jayaswal, R. K. (2000). Molecular characterization of a ferric uptake regulator, Fur, from Staphylococcus aureus. Microbiology 146, 659-668.

Edited by: J. A. Lindsay 